\title{
High-level expression and production of human lactoferrin in Pichia pastoris
}

\author{
Tiemin JIANG ${ }^{1}$, Lijun $\mathrm{CHEN}^{1}{ }^{*}$, Shiqian $\mathrm{JIA}^{1}$, Lishui CHEN ${ }^{2}$, Ying $\mathrm{MA}^{2}$ \\ ${ }^{1}$ Technical Center, Beijing Sanyuan Foods CO, LTD, Beijing, 100085, P. R. China \\ ${ }^{2}$ College of Food Science and Engineering, Harbin Institute of Technology, Harbin, 150090, P. R. China
}

Received 27 January 2007 - Accepted 29 August 2007

\begin{abstract}
Lactoferrin (LF) is a multifunctional iron-binding glycoprotein which is found in high concentrations in milk. Recombinant human LF (rhLF) may provide health benefits. In the present study, we report an optimization of the production system of recombinant human lactoferrin that has enabled the production of recombinant protein at levels up to $1200 \mathrm{mg} \cdot \mathrm{L}^{-1}$. The hLF was expressed in the methylotrophic yeast Pichia pastoris using the pPIC9K vector. The expression level of recombinant hLF (rhLF) was improved significantly by mixed methanol/glycerol feeding at the ratio of 4:1 during the induction phase of high cell-density fermentation. A yield of approximately $1200 \mathrm{mg} \cdot \mathrm{L}^{-1}$ was obtained in fed-batch fermentation with this system, which was much higher than the reported values for other systems $\left(1 \mathrm{mg} \cdot \mathrm{L}^{-1}\right.$ to $\left.115 \mathrm{mg} \cdot \mathrm{L}^{-1}\right)$. The rhLF was purified via ionexchange chromatography using SP Sepharose ${ }^{\mathrm{TM}}$ Fast Flow and has a similar molecular mass of $80 \mathrm{~kg} \cdot \mathrm{mol}^{-1}$ to native hLF. The level of glycosylation of the recombinant protein is similar to that of the native protein.
\end{abstract}

human lactoferrin / Pichia pastoris / high cell-density fermentation / glycosylation

摘要 - 毕赤酵母高效表达和生产人乳铁蛋白。乳铁蛋白 (LF) 是一种具有多种生物功能的 铁结合糖蛋白, 主要存在于动物乳汁, 而重组人乳铁蛋白能给人类健康带来利益。本文报道 了一种理想的重组人乳铁蛋白表达系统, 醇毕赤酵母中实现。该表达系统在细胞高密度发 酵条件下, 以 $4: 1$ 的甲醇/甘油为诱导剂, 使重组乳铁蛋白表达量达到 $1200 \mathrm{mg} \cdot \mathrm{L}^{-1}$, 显著高于 目前报道的其它表达系统 $\left(1 \sim 115 \mathrm{mg} \cdot \mathrm{L}^{-1}\right)$ 。而经离子交换层析 (SP sepharose ${ }^{\mathrm{TM}}$ Fast Flow) 纯化的重组人乳铁蛋白具有与天然蛋白相近的分子量 (约 80 千道尔顿) 和相似的糖基化水 平。

\section{人乳铁蛋白 / 毕赤酵母 / 细胞高密度发酵 / 糖基化}

Résumé - Haut niveau d'expression et de production de lactoferrine humaine par Pichia pastoris. La lactoferrine (LF) est une glycoprotéine multifonctionnelle liant le fer, qui se trouve en concentration élevée dans le lait. La lactoferrine humaine recombinante (rhLF) peut être bénéfique pour la santé. Dans cette étude, nous présentons une optimisation du système de production de rhLF permettant d'obtenir des niveaux de production élevés. La lactoferrine humaine était exprimée dans la levure méthylotrophe Pichia pastoris à l'aide du vecteur pPIC9K. Le niveau d'expression de rhLF était amélioré significativement lorsque le milieu était alimenté d'un mélange méthanol/glycérol dans un ratio de 4:1 pendant la phase d'induction de la fermentation à haute densité cellulaire.

*Corresponding author (通讯作者): chlj@263.net 
Un rendement d'approximativement $1200 \mathrm{mg} \cdot \mathrm{mL}^{-1}$ était obtenu en fermentation batch alimenté avec ce système, ce qui était beaucoup plus élevé que les valeurs reportées pour d'autres systèmes $\left(1 \mathrm{mg} \cdot \mathrm{L}^{-1}\right.$ à $\left.115 \mathrm{mg} \cdot \mathrm{L}^{-1}\right)$. La rhLF était purifiée par chromatographie d'échange d'ions (SP Sepharose ${ }^{\mathrm{TM}}$ Fast Flow) et avait une masse moléculaire de $80 \mathrm{~kg} \cdot \mathrm{mol}^{-1}$ similaire à celle de la lactoferrine humaine native. Le degré de glycosylation de la protéine recombinante était similaire à celui de la protéine native.

\section{lactoferrine humaine / Pichia pastoris / fermentation / glycosylation}

\section{INTRODUCTION}

Lactoferrin (LF) is an $80 \mathrm{~kg} \cdot \mathrm{mol}^{-1}$ member of the transferrin family of iron-binding glycoproteins, which was originally found in mammalian exocrine secretions and in specific granules of polymorphonuclear leukocytes $[3,11]$. Human LF (hLF) is present at high concentrations (average 1 to $3.2 \mathrm{mg} \cdot \mathrm{mL}^{-1}$ ) and plays a significant protective role in human milk. Several biological functions have been ascribed to LF including iron homeostasis, antimicrobial activity against bacteria and fungi, modulation of immunity and inflammation, cell growth regulation, and cancer protection $[15,27]$. And commercial interest in such materials is increasing because consumers who demand "natural" and healthful foods and cosmetics that contain no manmade preservatives are increasing. In addition, the hLF should be useful as a functional component of new clinical foods for prevention or treatment of gastrointestinal infections, especially in neonates. To meet these aspects, large amounts of hLF are required. Although hLF has been expressed in various systems $[1,10,12,13,16,19,26,28]$, the potential nutritional and therapeutic application of hLF has not been exploited so far due to the lack of an inexpensive method for the production of sufficient quantities of functional LF for commercial use. Ying et al. [28] have reported the production of rhLF in the methylotrophic yeast Pichia pastoris, but the level was moderate, with the highest production of $115 \mathrm{mg} \cdot \mathrm{L}^{-1}$. In the present study, we ob- tained a yield of $1200 \mathrm{mg} \cdot \mathrm{L}^{-1}$ of recombinant human lactoferrin in $P$. pastoris cells by selecting multicopy transformants and fed-batch fermentation. The yield is much higher than those reported previously.

\section{MATERIALS AND METHODS}

\subsection{Materials}

All restriction enzymes, T4 DNA ligase, Taq DNA polymerase and Plasmid Extraction Kits were purchased from Promega (Charbonnières, France). DNA primers were synthesized by TaKaRa Biotechnology (Dalian) Co., Ltd. (TaKaRa Dalian, China). pPIC9K and $P$. pastoris KM71 were obtained from Invitrogen (Carlsbad, CA, USA). The SP Sepharose ${ }^{\mathrm{TM}}$ Fast Flow was obtained from Pharmacia Biotech Inc. (Uppsala, Sweden). The hLF strandard and Peptide-N-glycosidase F (PNGase F) were from Sigma (St. Louis, MO, USA). Polyclonal antibodies against hLF (rabbit) were the product of Dako (Glostrup, Denmark). The secondary antibody (goat anti-rabbit), antibiotic G418, ampicillin and the immunoreaction detection system were purchased from Beijing Xin Jing Ke Biotechnology Co., Ltd. (Beijing, China). KLF2000 3.7 L fermentor was obtained from Bioengineering AG (Wald, Switzerland) and the ultrafiltration system was obtained from Pall Filtron Corp. (Beijing, China). Peptone, yeast extract and yeast nitrogen base (YNB) were obtained from Difco (Detroit, MI, USA). 


\subsection{Strains and growth media}

Escherichia coli TOP10F' (Invitrogen) was used for plasmid transformation and preparation. The $P$. pastoris strain was prepared in YPD broth ( $1 \%$ yeast extract, $2 \%$ peptone, $2 \%$ dextrose) at $30{ }^{\circ} \mathrm{C}$ for $2 \mathrm{~d}$ before fermentation, and the fermentor media were basal salts medium $\left(26.7 \mathrm{~mL} \cdot \mathrm{L}^{-1} \mathrm{H}_{3} \mathrm{PO}_{4}, 0.74 \mathrm{~g} \cdot \mathrm{L}^{-1}\right.$ $\mathrm{CaSO}_{4}, 18.2 \mathrm{~g} \cdot \mathrm{L}^{-1} \quad \mathrm{~K}_{2} \mathrm{SO}_{4}, 14.9 \mathrm{~g} \cdot \mathrm{L}^{-1}$ $\mathrm{MgSO}_{4} \cdot 7 \mathrm{H}_{2} \mathrm{O}, 4.13 \mathrm{~g} \cdot \mathrm{L}^{-1} \mathrm{KOH}$ and $40 \mathrm{~g} \cdot \mathrm{L}^{-1}$ glycerol) and trace metals solution PTM1 $\left(6.0 \mathrm{~g} \cdot \mathrm{L}^{-1} \mathrm{CuSO}_{4}, 0.8 \mathrm{~g} \cdot \mathrm{L}^{-1}\right.$ $\mathrm{KI}, \quad 3.0 \mathrm{~g} \cdot \mathrm{L}^{-1} \quad \mathrm{MnSO}_{4} \cdot \mathrm{H}_{2} \mathrm{O}, \quad 0.2 \mathrm{~g} \cdot \mathrm{L}^{-1}$ $\mathrm{Na}_{2} \mathrm{MoO}_{4} \cdot 2 \mathrm{H}_{2} \mathrm{O}, \quad 0.2 \quad \mathrm{~g} \cdot \mathrm{L}^{-1} \quad \mathrm{H}_{3} \mathrm{BO}_{3}$, $0.5 \mathrm{~g} \cdot \mathrm{L}^{-1} \mathrm{CaSO}_{4} \cdot 2 \mathrm{H}_{2} \mathrm{O}, 20 \mathrm{~g} \cdot \mathrm{L}^{-1} \mathrm{ZnCl}_{2}$, $65 \mathrm{~g} \cdot \mathrm{L}^{-1} \mathrm{FeSO}_{4} \cdot 7 \mathrm{H}_{2} \mathrm{O}, 0.2 \mathrm{~g} \cdot \mathrm{L}^{-1}$ Biotin and $5 \mathrm{~mL} \cdot \mathrm{L}^{-1} 98 \% \mathrm{H}_{2} \mathrm{SO}_{4}$ ), the ingredients of which were the same as described by Stratton et al. [23].

\subsection{Construction of the expression vector}

A human breast tumour cDNA library was initially screened by PCR and the cDNA sequence encoding LF without signal sequence was amplified from PCR using the specific primer pair P1 (5'CGAATTCGGCCGTAGGAGAAGGAGTGT-3') and P2 (5'-GCGGCCGCTTACTTCCTGAGGAATTCAC-3') which contain EcoRI and NotI sites, respectively. The PCR product was cloned into the EcoRINot I sites of pPIC9K to produce the expression plasmid pPIChLF, in which the $h L F$ should be under methanol-inducible alcohol oxidase (AOX1) promoter control. The gene insertions at the EcoRI site of pPIC9K were used to generate an in-frame protein fusion of the inserted DNA with the Saccharomyces cerevisiae $\alpha$-mating factor signal sequence to enable the secretion of recombinant protein.

\subsection{Transformation of $P$. pastoris and screening for secretion of rhLF}

The pPIChLF expression vector was propagated in E. coli $\mathrm{TOP}_{10 \mathrm{~F}^{\prime}}$, and the plasmid was isolated from the positive transformant $\mathrm{TOP} 10 \mathrm{~F}^{\prime}$ clone. It was digested with SalI and electroporated into the his4 locus of the chromosomal DNA of $P$. pastoris strain KM71 using an electroporator (MicroPulser, Bio-Rad, Hercules, CA, USA). After 4 days of incubation at $30{ }^{\circ} \mathrm{C}$ on YPD plates, isolated clones were streaked on minimal plates without histidine to obtain the $\mathrm{His}^{+}$strain that can grow without histidine. Genomic insertion was confirmed by PCR analysis on genomic DNA with $\mathrm{P} 1 / \mathrm{P} 2$ primers. His ${ }^{+}$transformants carrying the $k a n^{\mathrm{r}}$ gene were further selected for multiple integrated copies by replating on G418 antibiotic according to the method described in the pPIC9K instruction manual (Invitrogen). To determine the expression level, clones resistant to different concentrations of G418 (0.5, 1, 2, 4 and $8 \mathrm{mg} \cdot \mathrm{mL}^{-1}$ ) were inoculated in $5 \mathrm{~mL}$ YPD medium and incubated at $250 \mathrm{rpm}$ and $30{ }^{\circ} \mathrm{C}$ for $24 \mathrm{~h}$, and the cells harvested by centrifugation were incubated at a seeding density of $0.1-0.2$ OD in BMMY $\left(100 \mathrm{mmol} \cdot \mathrm{L}^{-1}\right.$ potassium phosphate, $\mathrm{pH} 6.0,1 \%$ yeast extract, $2 \%$ peptone, $1.34 \% \mathrm{YNB}, 400 \mu \mathrm{g} \cdot \mathrm{L}^{-1}$ biotin and $0.5 \%$ methanol) medium to induce the expression of hLF. Methanol was again added to a final concentration of $0.5 \%$ $(\mathrm{v} / \mathrm{v})$, repeated every $24 \mathrm{~h}$ to maintain induction. The medium supernatant was collected and the secreted rhLF was quantified by an enzyme-linked immunosorbent assay (ELISA) according to the method described by Salmon [22]. The supernatant for analysis of SDS-PAGE was concentrated by freeze-drying and resuspended in distilled water. In addition, the standard hLF as a control was also analyzed under identical conditions. 


\subsection{Fed-batch fermentation}

After shake-flask analysis, indicating that rhLF expression was optimal with the strain resistant to $4 \mathrm{mg} \cdot \mathrm{mL}^{-1} \mathrm{G} 418$, the strain was tested by fed-batch fermentation. Several fermentation strategies have been investigated in order to find an efficient scheme for the production of heterologous protein in P. pastoris. For slow methanol utilization $\left(\mathrm{Mut}^{\mathrm{s}}\right)$ phenotype strains, such as KM71, the most common strategy seen in high-productivity recombinant Pichia fermentation uses a two-stage feeding protocol $[8,14]$.

The best protein-expressing clone selected by ELISA was used for fermentation analysis, which was carried out in the KLF2000 3.7 L fermentor. The fermentation process was as follows: firstly, inoculate $200 \mathrm{~mL}$ YNB containing 2\% glycerol with cells from a single colony of the multicopy transformant, and incubate overnight with shaking. Secondly, add this culture to the fermentor containing $2 \mathrm{~L}$ basal salts plus $6 \mathrm{~mL} \cdot \mathrm{L}^{-1} \mathrm{PTM} 1$ salts and $4 \%$ glycerol. Dissolved oxygen (DO) is set at $30 \pm 5 \%$ and $\mathrm{pH}$ is maintained at 6.0 by the addition of $30 \% \mathrm{NH}_{4} \mathrm{OH}$. Thirdly, allow to grow at $30{ }^{\circ} \mathrm{C}$ until glycerol is exhausted, and this initial glycerol batch phase usually lasts $20 \sim 30$ h. Finally, 30 min after the exhaustion of glycerol, the induction stage was initiated by feeding a mixture of methanol and glycerol at a ratio of $4: 1$. DO was maintained at greater than $70 \%$ of saturation by regulating the feed rate during fermentation and $\mathrm{pH}$ at 4.5 in order to maintain the optimal expression and cumulation of rhLF.

\subsection{Analysis of rhLF}

The rhLF accumulation was observed by Western blotting analysis every $12 \sim 24 \mathrm{~h}$ and the yield quantified with reversed-phase high-performance liquid chromatography (RP-HLPC, LC10ATvp, Shimadzu Corporation, Tokyo, Japan). The C18 reversed-phase column $(2.2 \times 25 \mathrm{~cm})$ was equilibrated with $0.05 \%$ trifluoroacetic acid (TFA). The sample of $20 \mu \mathrm{L}$, desalted and adjusted to $0.05 \%$ TFA, was loaded at $4 \mathrm{~mL} \cdot \mathrm{min}^{-1}$, and eluted with a 20:80 mixture of $0.05 \%$ TFA and $90 \%$ acetonitrile in $0.05 \%$ TFA at the same flow rate. The absorbance of the column eluent at $280 \mathrm{~nm}$ was monitored continuously.

\section{7. rhLF purification}

The induction phase continued for a further $48 \sim 60$ h. The supernatant collected by centrifuging was passed through in turn a $0.8-\mu \mathrm{m}$ filtration membrane and Centramate ultrafiltration membrane with $50 \mathrm{~kg} \cdot \mathrm{mol}^{-1}$ cutoff against $50 \mathrm{mmol} \cdot \mathrm{L}^{-1}$ $\mathrm{PBS} / 0.1 \mathrm{~mol} \cdot \mathrm{L}^{-1} \mathrm{NaCl}(\mathrm{pH} 8.5)$, and the ultrafiltrated broth was loaded onto a SP Sepharose $^{\mathrm{TM}}$ Fast Flow ion-exchange column at a flow rate of $100 \mathrm{~mL} \cdot \mathrm{h}^{-1}$. The proteins were eluted from the column using a linear gradient of $\mathrm{NaCl}\left(0.1 \sim 1.0 \mathrm{~mol} \cdot \mathrm{L}^{-1}\right)$ in $400 \mathrm{~mL}$ running buffer and collected into 99 tubes using a fraction collector. The proteins were identified by dot-blotting immunodetection and the tubes containing LF were pooled, dialyzed against PBS (pH 7.5) and checked on 12\% SDS-PAGE.

\subsection{Deglycosylation analysis}

Deglycosylation of recombinant $\mathrm{hLF}$ and native $\mathrm{hLF}$ as standard was performed under identical conditions using PeptideN-glycosidase F (PNGase F) according to the protocols described by the manufacturer. $20 \mu \mathrm{g}$ purified and standard hLF diluted in $20 \mu \mathrm{L}$ twice-distilled $\mathrm{H}_{2} \mathrm{O}$ were boiled for $10 \mathrm{~min}$ in $1 \mathrm{X}$ glycoprotein denaturing buffer $(0.5 \%$ SDS and $1 \%$ $\beta$-mercaptoethanol) to expose fully all glycosylation sites, and then incubated with 
one unit PNGase $\mathrm{F}$ in $1 \mathrm{X}$ G7 reaction buffer $\left(50 \mathrm{mmol} \cdot \mathrm{L}^{-1}\right.$ sodium phosphate, $\mathrm{pH} 7.5$ ) supplemented with $1 \% \mathrm{NP}-40$ at $37{ }^{\circ} \mathrm{C}$ for $2 \mathrm{~h}$. The treated and untreated hLF were analyzed by SDS-PAGE.

\section{RESULTS AND DISCUSSION}

\subsection{Transformation and screening}

Positive cDNA clones were isolated from the mammary cDNA library by PCR screening. Sequence analysis revealed that the full-length cDNA $(2.5 \mathrm{~kb})$ of human LF contained an open reading frame of 2076 bp, encoding a 692 amino acid residue with a calculated molecular mass of $80 \mathrm{~kg} \cdot \mathrm{mol}^{-1}$. Alignment analysis revealed that it shares high similarity with human lactoferrin cloned by Rey [20] except 14 base pairs. The cDNA corresponding to the coding sequence of mature hLF was ligated into the EcoRI-NotI sites of pPIC9K, and the linear recombinant $\mathrm{pPIChLF}$ vector with correct orientation of hLF cDNA checked by DNA sequencing was used to transform the KM71 strain of $P$. pastoris. The phenotype of transformants is a slow growth phenotype $\left(\mathrm{Mut}^{\mathrm{s}}\right)$ with methanol as the sole carbon source, since $A O X 1$ was already disrupted in $\mathrm{KM} 71$, and the Mut ${ }^{\mathrm{s}}$ clones were selected on minimal plates without histidine and chosen for further study. PCR analysis of genomic DNA revealed the presence of the band corresponding to hLF (Fig. 1), which showed that the $h L F$ had integrated into the P. pastoris genome.

Multiple plasmid integration events occur spontaneously in Pichia at a frequency between 1 and $10 \%$ of all $\mathrm{His}^{+}$ transformants, and increasing the copy number of recombinant genes usually increases expression levels of recombinant proteins $[5,6]$. With secreted protein, the effects of the gene copy number are not as simple; they must be empirically determined for each recombinant protein.

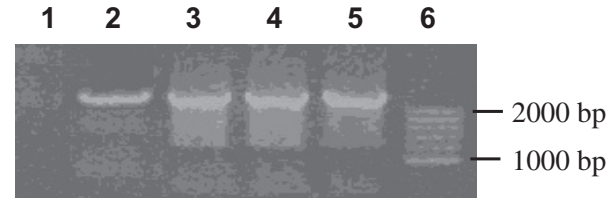

Figure 1. PCR results of transformants. Lane 1, the non-transformed strain of P. pastoris; lane 2, pPIC9K/hLF; lanes 3-5, positive clones; lane 6 , DNA 200 bp step ladder.

Isolating transformants with a high vector copy number can be achieved simply by using a drug selection vector, such as pPIC9K, that contains the Tn903 kan gene, which confers dose-dependent resistance upon the antibiotic G418 in P. pastoris [21]. In this study, $\mathrm{His}^{+}$transformants carrying the $k a n^{\mathrm{r}}$ gene are further selected for multiple integrated copies by replating on G418 antibiotic at different concentrations. The relationship between the level of resistance to G418 and the expression level of hLF is shown in Figure 2. There is a good correlation between the ability of resistance to G418 (e.g. gene copy numbers) and the yield of hLF. Usually, G418 selection at the highest practical concentration of $2 \sim 4 \mathrm{mg} \cdot \mathrm{mL}^{-1}$ can very rapidly isolate transformants with $>5$ integrated vector copies, which are usually sufficient for high-level expression, but it cannot differentiate transformants with copy numbers $>5$.

\subsection{Optimization of hLF expression}

Fermentation growth is especially important for secreted protein, as the concentration of product in the medium is roughly proportional to the concentration of cells in the culture. Another positive aspect of growing $P$. pastoris in fermenter cultures is that the level of transcription initiated from the $A O X 1$ promoter can be $3 \sim 5$ times greater in cells fed methanol at growthlimiting rates compared with cells grown in 
a

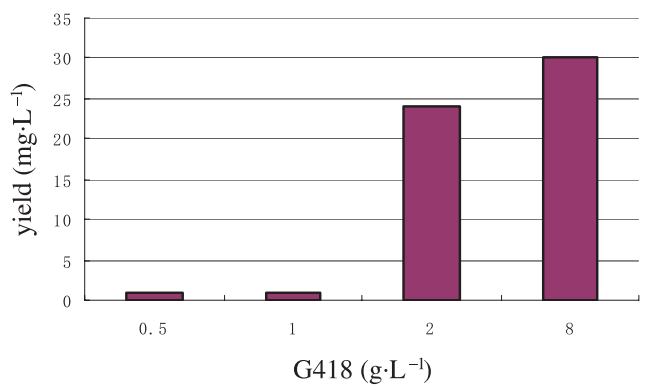

b

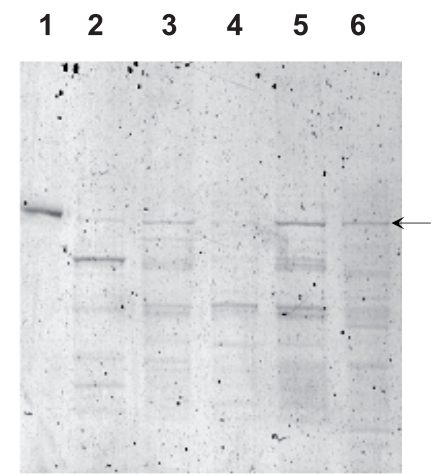

Figure 2. Correlation between the level of resistance to G418 and the expression level of rhLF by shake-flask analysis. (a) The yield (mg. $\mathrm{L}^{-1}$ ) was measured with ELISA and the standard error for all data was less than $10 \%$. (b) Lane 1 is $5 \mu \mathrm{L}$ standard hLF, which comes from human milk $\left(\sim 80 \mathrm{~kg} \cdot \mathrm{mol}^{-1}\right)$; lanes 2-6 are fermentation supernatant fractions of different clones resistant to 0.5 , $1.0,2.0,4.0$ and $8.0 \mathrm{mg} \cdot \mathrm{mL}^{-1} \mathrm{G} 418$, respectively. The site of the bands corresponding to rhLF is indicated by an arrow.

4

5

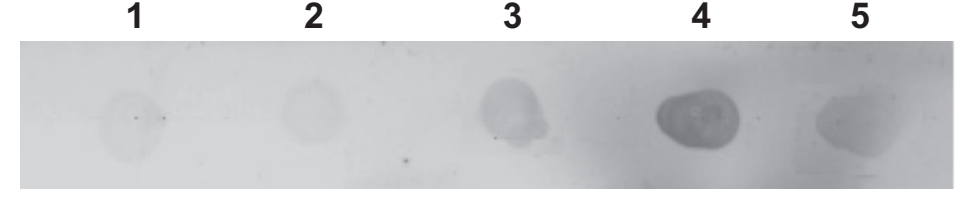

Figure 3. Dot-immunoblotting analysis of rhLF from fermentation with different inducers. Following $60 \mathrm{~h}$ of inducing, cultures were harvested and the supernatant was spotted directly on the PVDF membrane to analyze by dot blotting. Lanes $1-5$ are the expression levels of rhLF of $1: 1,2: 1,3: 1$, 4:1 and 5:1 of methanol and glycerol, respectively.

a shake flask [4,5]. Furthermore, the $A O X 1$ promoter is regulated by a combination of repression/derepression by glycerol and induction by methanol. The combined regulation mechanism allows the feeding simultaneously of methanol and glycerol and has been shown to improve the yield of recombinant Pichia pastoris fermentation systems, especially those exhibiting a Mut ${ }^{\mathrm{s}}$ phenotype [14, 24].

The Pichia pastoris system has now been used successfully to express a large number of intracellular and secreted proteins. Extremely high levels have been obtained for some biologically active molecules [6], and LF has been shown to be expressed in P. pastoris with the highest yield of $115 \mathrm{mg} \cdot \mathrm{L}^{-1}[17,18,25,28]$. In this paper, the effect of the ratio of glycerol and methanol on the expression of hLF and the growth of yeast cells were determined by dot blotting and OD600. It was found that feeding methanol and glycerol with a ratio of $4: 1$ could improve the yield of expression of recombinant hLF (Fig. 3), but it was not optimal for cell growth (Tab. I). Little difference was observed between the other ratio of methanol and glycerol, indicating that mixed feeding at high glycerol or methanol levels could result in inhibition of expression in $\mathrm{Mut}^{\mathrm{s}}$ yeast. Time-course studies with clones resistant to G418 at $4 \mathrm{mg} \cdot \mathrm{L}^{-1}$ showed that rhLF in the culture media accumulated increasingly with 
Table I. Biomass concentrations of yeast cells from fermentation with different inducers.

\begin{tabular}{llllll}
\hline $\begin{array}{l}\text { Ratio of methanol } \\
\text { and glycerol }\end{array}$ & $1: 1$ & $2: 1$ & $3: 1$ & $4: 1$ & $5: 1$ \\
\hline OD600 & 74.9 & 75.2 & 73.3 & 72.0 & 76.6 \\
\hline & & & & & \\
1 & $\mathbf{2}$ & $\mathbf{3}$ & $\mathbf{4}$ & $\mathbf{5}$ \\
\end{tabular}

Figure 4. Time-course of expression of rhLF analyzed by Western blotting. Samples were taken at $0 \mathrm{~h}$ (lane 1), $12 \mathrm{~h}$ (lane 2), $48 \mathrm{~h}$ (lane 3) and $60 \mathrm{~h}$ (lane 4) after induction with a mixture of methanol and glycerol. Lane 5 is native hLF.

fermentation and a maximum production was reached after $60 \mathrm{~h}$ under the conditions described above (Fig. 4). This yield was measured by RP-HPLC. As shown in Figure 5 , based on the peak heights of yeast broth and standard hLF $\left(1.0 \mathrm{mg} \cdot \mathrm{mL}^{-1}\right)$, it is estimated that the concentration of expression $\mathrm{hLF}$ was about $1.2 \mathrm{mg} \cdot \mathrm{mL}^{-1}$, which is significantly higher than those reported by Liang and Richardson [12] and Ying et al. [28]. In addition, the secretion of recombinant LF can increase by adjusting the initial $\mathrm{pH}$ of the culture from 6 to 7 and by the addition of ferric ions at $100 \mu \mathrm{mol} \cdot \mathrm{L}^{-1}$ to the medium [25].

\subsection{Protein purification and deglycosylation analysis}

Pichia pastoris is a single-cell microorganism that is easy to manipulate and cultivate. As a yeast, it is capable of many of the posttranslational modifications performed by higher eukaryotic cells, such as proteolytic processing, folding and glycosylation [7,9]. Human milk LF is known to have two poly-N-acetylacetyl-lactosaminic glycans that contain
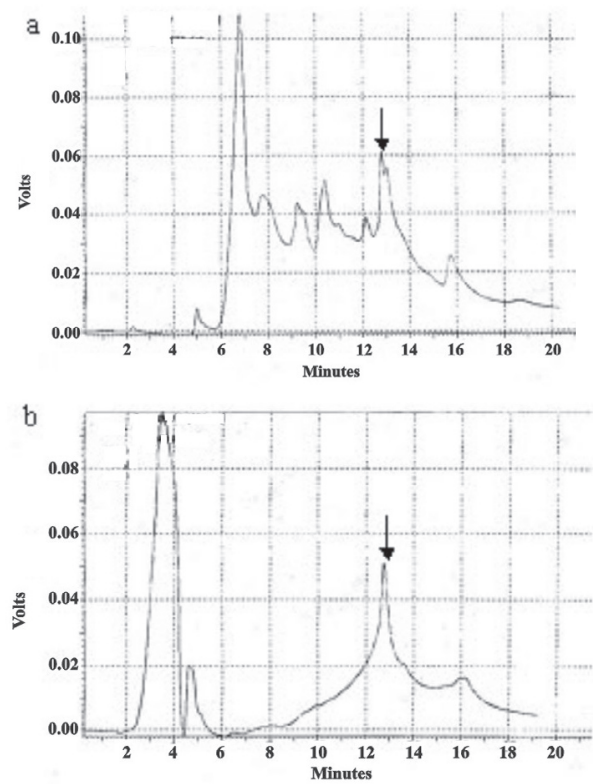

Figure 5. RP-HPLC chromatograms of recombinant hLF (a) and standard hLF (b). The hLF peak is indicated by an arrow.

$\mathrm{N}$-acetylneuraminic acid (sialic acid), fucose and galactose, one located in the $\mathrm{C}$ and the other in the $\mathrm{N}$-terminal zone in its native host [11]. To evaluate the glycosylation levels of the recombinant hLF (rhLF), the expression product was firstly purified by an anion-exchange chromatography procedure. The protein was eluted as a single peak from $0.6 \sim 0.8 \mathrm{~mol} \cdot \mathrm{L}^{-1}$ from the $\mathrm{NaCl}$ gradient and these fractions were analyzed by dot blotting (not shown). All protein samples containing rhLF were desalted for analysis by SDS-PAGE (Fig. 6). Two strong bands of 80 and $66 \mathrm{~kg} \cdot \mathrm{mol}^{-1}$, corresponding to hLF, were detected and gave a positive reaction with a polyclonal antibody raised against native hLF (not shown). The results of deglycosylation of rhLF and native hLF with PNFGase F are shown in Figure 6. The difference between digested and undigested hLF suggests that the recombinant protein was glycosylated by the $P$. pastoris cells. 


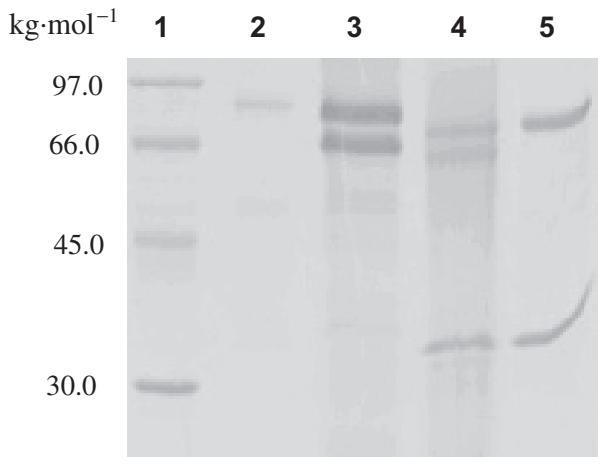

Figure 6. Deglycosylation test of recombinant hLF. Lane 1: protein MW marker; lane 2: native hLF; lane 3: recombinant hLF; lane 4: recombinant hLF digested with PNGase F; lane 5: native hLF digested with PNGase F.

The structures of polypeptide chains and carbohydrate moieties of hLF are well established. hLF consists of a 692 amino acid polypeptide chain to which two complex-type glycans are linked by $\mathrm{N}$ glycosylation at Asn137 and Asn478. The majority of therapeutically relevant proteins appears to be glycosylated in nature and therefore must be glycosylated in order to display the correct biological activity. It is postulated that the general function of protein glycosylation is to aid in the folding of the nascent polypeptide chain and in the stabilization of the conformation of the mature glycoprotein [2]. Although yeast cells recognize the same type of $\mathrm{N}$ glycosylation sequence and potentially at least glycosylate at the same sites as higher eukaryotic cells, they have their glycosyl groups consisting primarily of mannose residues appended in different linkages to the core glycosyl units [4]. In this paper, the glycosylation analysis showed that the rhLF was glycosylated in $P$. pastoris cells (Fig. 6), but further study of its glycosylation patterns and glycan structure is needed.
Acknowledgements: This work was financially supported by the National Technology Research and development program of China (2001BA501A12).

\section{REFERENCES}

[1] Berkel H.C., Welling M.W., Geerts M., van Veen H.A., Ravensbergen B., Salaheddine M., Pauwels K.J., Piper F., Nuijens J.H., Nibbering P.H., Large scale production of recombinant human lactoferrin in the milk of transgenic cows, Nat. Biotechnol. 20 (2002) 484-487.

[2] Borgheresi R.A.M.B., Ducancel F., Camargo A.C.M., Carmona E., Palma M.S., Expression and processing of recombinant sarafotoxins precusor in Pichia pastoris, Toxicon 39 (2001) 1211-1218.

[3] Brock J.H., The physiology of lactoferrin, Biochem. Cell Biol. 80 (2002) 1-6.

[4] Cereghino J.L., Cregg J.M., Heterologous protein expression in the methylotrophic yeast Pichia pastoris, FEMS Microbiol. Rev. 4 (2001) 45-66.

[5] Clare J.J., Romanos M.A., Rayment F.B., Rowedder J.E., Smith M.A., Payne M.M., Sreekrishna K., Henwood C.A., Production of mouse epidermal growth factor in yeast: High level secretion using Pichia pastoris strains containing multiple gene copies, Gene 105 (1991) 205-212.

[6] Clare J., Sreekrishna K., Romanos M., Expression of tetanus toxin fragment C, Methods Mol. Biol. 103 (1998) 193-208.

[7] Cremata J.A., Montesino R., Quintero O., Garcia R., Glycosylation profiling of heterologous proteins, Methods Mol. Biol. 103 (1998) 95-105.

[8] d'Anjou M.C., Daugulis A.J., Mixed-feed exponential feeding for fed-batch culture of recombinant methylotrophic yeast, Biotechnol. Lett. 22 (2000) 341-346.

[9] Higgins D.R., Cregg J.M., Introduction to Pichia pastoris, Methods Mol. Biol. 103 (1998) 1-15.

[10] Kim S.J., Sohn B.H., Jeong S.K., Pak K.W., Park J.S., Park I.Y., Lee T.H., Choi Y.H., Lee C.S., Han Y.M., Yu D.Y., Lee K.K., Highlevel expression of human lactoferrin in milk of transgenic mice using genomic lactoferrin sequence, J. Biochem. 126 (1999) 320-325.

[11] Levay P.F., Viljoen M., Lactoferrin: a general review, Haematologica 80 (1995) 252-267. 
[12] Liang Q.W., Richardson T., Expression and characterization of human lactoferrin in yeast Saccharomyces cerevisiae, J. Agric. Food Chem. 41 (1993) 1800-1807.

[13] Liu Z., Zhao C., Fan B., Dai Y., Zhao Z., Wang L., Zheng M., Feng J., Chen Y., Duan Y., Li N., Variable expression of human lactoferrin gene in mice milk driven by its $90 \mathrm{~kb}$ upstream flanking sequences, Anim. Biotechnol. 15 (2004) 21-31.

[14] Loewen M.C., Liu X., Davies P.L., Biosynthetic production of type II fish antifreeze protein: fermentation by Pichia pastoris, Appl. Microbiol. Biotechnol. 48 (1997) 480-486.

[15] Lonnerdal B., Iyer S., Lactoferrin: molecular structure and biological function, Annu. Rev. Nutr. 15 (1995) 93-110.

[16] Nandi S., Suzuki Y.A., Huang J.M., Yalda D., Pham P., Wu L.Y., Bartley G., Expression of human lactoferrin in transgenic rice grains for the application in infant formula, Plant Sci. 163 (2002) 713-722.

[17] Paramasivam M., Saravanan K., Uma K., Sharma S., Singh T.P., Srinivasan A., Expression, purification, and characterization of equine lactoferrin in Pichia pastoris, Protein Expr. Purif. 26 (2002) 28-34.

[18] Pecorini C., Savazzini F., Martino P.A., Fusi E., Fogher C., Baldi A., Heterologous expression of biologically active porcine lactoferrin in Pichia pastoris yeast, Vet. Res. Commun. 29 (2005) 379-382.

[19] Rachmawati D., Mori T., Hosaka T., Takaiwa F., Inoue E., Anzai H., Production and characterization of recombinant human lactoferrin in transgenic Javanica rice, Breed. Sci. 55 (2005) 213-222.

[20] Rey M.W., Woloshuk S.L., deBoer H.A., Pieper F.R., Complete nucleotide sequence of human mammary gland lactoferrin, Nucl. Acid Res. 18 (1990) 5288.

[21] Romanos M., Scorer C., Sreekrishna K., Clare J., The generation of multicopy recombinant strains, Methods Mol. Biol. 103 (1998) 55-72.

[22] Salmon V., Slomianny M.C., El Yazidi I., Spik G., Gruber V., Bournat P., Olagnier B., Mison D., Theisen M., Merot B., Legrand D., Production of human lactoferrin in transgenic tobacco plants, Protein Expr. Purif. 13 (1998) 127-135.

[23] Stratton J., Chiruvolu V., Meagher M., High cell-density fermentation, Methods Mol. Biol. 103 (1998) 107-120.

[24] Thorpe E.D., d'Anjou M.C., Daugulis A.J., Sorbitol as a non-repressing carbon source for fed-batch fermentation of recombinant Pichia pastoris, Biotechnol. Lett. 21 (1999) 669-672.

[25] Wang S.H., Yang T.S., Lin S. M., Tsai M.S., Wu S.C., Mao S.J.T., Expression, characterization, and purification of recombinant porcine lactoferrin in Pichia pastoris, Protein Expr. Purif. 25 (2002) 41-49.

[26] Ward P.P., May G.S., Headon D.R., Conneely O.M., An inducible expression system for the production of human lactoferrin in Aspergillus nidulans, Gene 122 (1992) 352-363.

[27] Ward P.P., Paz E., Conneely O.M., Multifunctional roles of lactoferrin: a critical overview, Cell Mol. Life Sci. 62 (2005) 2540-2548.

[28] Ying G., Wu S.H., Wang J., Zhao X.D., Chen J.M., Zhang X.G., Hou Y.D., Producing human lactoferrin by high-density fermentation recombinant Pichia pastoris, Chin. J. Exp. Clin. Virol. 18 (2004) 181-185. 